\title{
Resúmenes Trabajos Finales Integradores: Especialización en Vinculación y Gestión Tecnológica
}

\section{Estrategias de knowledge management y su implementación en una pyme de $\mathrm{I}+\mathrm{D}+\mathrm{i}$ santafesina. Caso de estudio: Laboratorio HORIAN I+D de CARBONFE}

\author{
Dr. Mariano Daniel Cristaldi \\ mariano.cristaldi@gmail.com \\ Director / Co-Director: Mag. María Lucila \\ Grand \\ Lugar de realización: Laboratorio Horian \\ I+D/CARBONFE. Facultad de Bioquímica \\ y Ciencias Biológicas. Universidad Nacional \\ del Litoral. \\ Fecha de la defensa: 11/12/2014
}

\section{Resumen}

El trabajo se enmarca dentro de los requisitos establecidos para acceder al título de Especialista en Gestión y Vinculación Tecnológica según lo ha definido el Comité Académico de la Facultad de Bioquímica y Ciencias Biológicas de la Universidad Nacional del Litoral.

En este trabajo se establece un marco conceptual y metodológico para analizar bajo la perspectiva de Caso de Estudio a una Empresa de Base Tecnológica de la provincia de Santa Fe, Argentina; para conocer, descubrir y establecer mecanismos que permitan responder a cómo una organización inteligente argentina aprende.

El Objetivo General se estableció como:

"Analizar, identificar y mejorar las estrategias de Gestión del Conocimiento implementadas en Laboratorio Horian I+D/CARBONFE para aprovechar de forma más eficiente el conocimiento generado por sus investigadores"

Para lograr ese Objetivo General y operativizarlo se definieron otros más específicos:

- Establecer un marco conceptual para el análisis de la Gestión del Conocimiento (GC) en organizaciones inteligentes locales que se adecue a las características del caso de estudio.

- Comprender los mecanismos para la generación de conocimiento y poder identificar las estrategias de GC utilizadas en la organización estudiada

- Proponer instrumentos que sirvan para evaluar el estado de la GC en la organización.

- Proponer indicadores para medir el impacto de la política de GC en la organización y evaluar su evolución en el período Enero - Diciembre de 2013.

Mediante la concreción de los últimos dos puntos se realiza un diagnóstico de la organización en relación a sus estrategias de GC estableciendo así el primer paso para la sistematización de la medición del impacto de las estrategias de GC esperando que de ese esfuerzo resulten líneas de acción para mejorarlas.

Así, son definidos y discutidos conceptos básicos como Conocimiento, Organización Inteligente, Gestión del Conocimiento y 
se detalla el abordaje metodológico como el modelo organizacional adoptado para el análisis, la forma en que fueron recolectados y tratados los datos, la evaluación de los Facilitadores Organizacionales de la GC, las herramientas utilizadas para el diagnóstico de la GC y la definición del sistema de indicadores de la GC propuesto.

La organización estudiada se presenta mediante una breve reseña histórica junto con una descripción concisa de sus actividades y de su estructura para contextualizarla dentro del Sistema Nacional de Innovación y dar una idea de la importancia de la GC en las actividades que desarrolla la empresa.

Todo lo anterior permite sustentar las conclusiones del trabajo tanto a nivel del análisis particular de las estrategias de GC de la organización tomada como Caso de Estudio como los aportes particulares de este trabajo en el contexto de la mejora de la gestión tecnológica. Además, son analizados los límites metodológicos y los potenciales inconvenientes en la implementación de la metodología en otras organizaciones.

\section{Summary}

Knowledge management strategies and their implementation into an innovative enterprise from Santa Fe, Argentina. Case of study: Laboratorio Horian I+D - CARBONFE

In this final paper for the Technological
Management Specialization of Facultad de Bioquímica y Ciencias Biológicas, Universidad Nacional del Litoral, the discipline of knowledge management is used to analyse an innovative entrerprise. Such analysis has been done from a case of study point of view in order to know, discover and describe those mechanisms involved in organizational learning and to propose a methodology for Argentinean intelligent organization study.

Firstly, a general conceptual framework is given to stablish the basis on which the case of study analysis is done. Laborarotio Horian I+D/CARBONFE is the studied organization which is a technology-based company whose headquarter is located in Santa Fe, Argentina; and belongs to Innovative National System.

In order to support the results and conclusions in this paper, a deep explanaition of objectives pursued is done altogether with a thorough discussion of methodological details, developed organizational models, research strategies and tools adopted to characterize the organization.

Finally conclusions are divided in two levels: i) organization level and, more importantly, ii) those related to both methodology implementation and extrapolation limits of knowledge management approach in other organizations. 


\section{Propuesta de pautas básicas de buenas prácticas de Vinculación Tecnológica para el mejoramiento y fortalecimiento de la gestión de la Oficina de Vinculación Tecnológica de la Facultad de Ingeniería de la Universidad Nacional de Entre Ríos}

\section{Cra. Maria Leticia Leiva}

marialeticialeiva@yahoo.com.ar

Director: Lic. Ana María Laffitte

Lugar de realización: Facultad de Ingeniería, Universidad Nacional de Entre Ríos. Facultad de Bioquímica y Ciencias Biológicas, Universidad Nacional del Litoral.

Fecha de la defensa: 03/11/2014

\section{Resumen}

El trabajo analiza la Oficina de Vinculación Tecnológica de la Facultad de Ingeniería de la Universidad Nacional de Entre Ríos a fin de fortalecer su capacidad de gestión, en el marco del sistema de vinculación tecnológica de la Universidad. La Facultad fue pionera (1984) en brindar el conocimiento de grado de la Bioingeniería, en la Argentina y en Latinoamérica junto con Méjico; posteriormente crea la primera carrera de Bioinformática (2005) en el país y en Sudamérica, proceso de crecimiento académico acompañado por el desarrollo de Maestrías en Ingeniería y Tecnología Biomédica y Doctorado en Ingeniería.

Los objetivos del trabajo son:

-Aportar a la mejora de los niveles de conocimiento de la situación actual a través de un diagnóstico de la gestión de los servicios y actividades de dicha oficina.

-Contribuir al fortalecimiento de los procesos de gestión de sus servicios y actividades.

-Proponer lineamientos para un sistema de buenas prácticas para la gestión de mejora del servicio de vinculación tecnológica de la oficina.

Se hace un recorrido de la historia, encuadre normativo, principales financiamientos y recursos y Buenas Prácticas para el desarrollo de la vinculación tecnológica en la Argentina, en la Universidad y en la Facultad. Para el diagnóstico situacional de la Oficina y propuesta de los lineamientos, metodológicamente se trabajó con:

a) Recopilación de la documentación de los proyectos gestionados, realizando un análisis cuantitativo.

b) Identificación y construcción de los procedimientos y modelos de gestión de proyectos.

c) Entrevistas a informantes calificados, realizando un análisis cualitativo.

\section{Summary}

Proposal of basic guidelines for best practices in technology transfer and liaison. Improving and strengthening management procedures at the Office of Technology Transfer and Liaison, Department of Engineering, National University of Entre Ríos

This paper studies the Office for Technology Transfer and Liaison at the Department of Engineering, National University of Entre Ríos, Argentina. It seeks to contribute to strengthen its management capacities within the framework of the University's technolo- 
gical linkage system. The Department of Engineering pioneered the degree of Bioengineering in Argentina, and in Latin America in conjuncture with Mexico. Afterwards it created the first degree program of Bioinformatics in the country and South America, triggering an academic growth process which was accompanied by the development of Master programs in Engineering and Biomedical Technology, as wells as a Doctoral degree in Engineering.

The objectives of this study are:

- to contribute to have a better understanding of the current situation through an deeper analysis of the management services and the activities carried out at the office

- to contribute to strengthen its management procedures and activities

- to propose guidelines for a good-prac- tice system aimed at managing quality improvements in the office.

The paper provides an overview of the history, legal framework, main funding sources and Best Practices policies for the development of technology transfer and linkages in Argentina, at the National University of Entre Ríos and the Department of Engineering. A specific methodology was developed to obtain a situation analysis of the Office and to provide recommendations, which entailed:

a) Compiling project documents, including quantitative analysis

b) Identifying and building procedures and models for project management

c) Interviewing qualified informants using a qualitative approach. 